\title{
Managing Controversies in the Fuzzy Front End
}

\author{
Christiansen, John K.; Gasparin, Marta
}

Document Version

Accepted author manuscript

Published in:

Creativity and Innovation Management

DOI:

10.1111/caim.12174

Publication date:

2016

License

Unspecified

Citation for published version (APA):

Christiansen, J. K., \& Gasparin, M. (2016). Managing Controversies in the Fuzzy Front End. Creativity and Innovation Management, 25(4), 500-514. https://doi.org/10.1111/caim.12174

Link to publication in CBS Research Portal

\section{General rights}

Copyright and moral rights for the publications made accessible in the public portal are retained by the authors and/or other copyright owners and it is a condition of accessing publications that users recognise and abide by the legal requirements associated with these rights.

Take down policy

If you believe that this document breaches copyright please contact us (research.lib@cbs.dk) providing details, and we will remove access to the work immediately and investigate your claim. 


\section{Managing Controversies in the Fuzzy Front End John K. Christiansen and Marta Gasparin}

Journal article (Post print version)

This is the peer reviewed version of the following article: Managing Controversies in the Fuzzy Front End. / Christiansen, John K.; Gasparin, Marta. In: Creativity and Innovation Management, 12.06.2016, which has been published in final form at http://dx.doi.org/10.1111/caim.12174.

This article may be used for non-commercial purposes in accordance with Wiley Terms and Conditions for Self-Archiving.

Uploaded to Research@CBS: September 2016 


\section{MANAGING CONTROVERSIES IN THE FUZZY FRONT END}

\section{ABSTRACT}

This research investigates the controversies that emerge in the fuzzy front end (FFE) and how they are closed so the innovation process can move on. The fuzzy front has been characterized in the literature, as a very critical phase, but controversies in the FFE has not been studied before.

The analysis investigates the microprocesses around the controversies that emerge during the fuzzy front end of four products. Five different types of controversies are identified: profit, production, design, brand and customers/market. Each controversy represents a threat, but is also an opportunity to search for new solutions in the unpredictable non-linear processes.

The study uses an ethnographic approach using qualitative data from interviews, company documents, external communication and marketing material, minutes of meetings, informal conversations and observations.

The analysis of four FFE processes demonstrates shows how the fuzzy front requires managers to deal with controversies that emerge from many different places and involve both human and non-human actors.

Closing the controversies requires managers to take account of the situation, identify the problem that needs to be addressed, and initiate a search for solutions. Management is actively involved in this process, in many different ways.

Among the implications from this analysis is that the managers' role in the FFE is multifaceted and each controversy seems to require different skills and competencies: as developer of business models, being able to comprehend production techniques and materials, acquiring financial support, igniting design alternatives, translating customer complaints, framing and stimulating design processes and designers, communicating across the different functional divisions in the company and participating in decision-making processes. 


\section{INTRODUCTION}

The fuzzy front end is frequently mentioned as the most critical phase of the innovation process (Frishammar, Lichtenthaler, \& Kurkkio, 2012; Frishammar, Lichtenthaler \& Richtnér, 2013; Koen et al., 2001) and management has to deal with it in order to develop new products (Kim \& Wilemon, 2002; Reid \& Brentani, 2004). The fuzzy front end (FFE) is defined as the early phases of a new product development (Khurana \& Rosenthal, 1998), the 'pre-project activities' (Verganti, 1997), that comprises ideation, project scoping, product definition, and building the business case (Cooper, 2008). In this paper, we adopt the definition from Khurana and Rosenthal (1998, p. 59) who define the front end 'to include product strategy formulation and communication, opportunity identification and assessment, idea generation, product definition, project planning, and executive reviews'. This include: (1) preliminary opportunity identification, idea generation, market and technology analysis and product and portfolio strategy alignment; (2) product concept; and (3) feasibility and project planning and the front end is 'complete' when a business unit either commits to the funding and launch of a new-product development project, or decides not to do this (Khurana \& Rosenthal, 1998). In the present study, we define the FFE process as lasting until the accepted prototype of a piece of furniture is ready for final product development, volume manufacturing and market launch, including design briefs, concept sketches, modeling, preliminary prototyping and modifications.

Prior studies on FFE have especially focused on how to reduce the uncertainty (Kim \& Wilemon, 2003), improve analytical capabilities in the FFE (Saff \& Ernst, 2003) and to develop approaches for facilitating the FFE (Thomke \& Fujimoto, 2000). These studies have presented interesting observations and suggestions, as in Reid and Brentani (2004) and Brentani and Reid (2012). Their assumption was that the FFE can be - or should be - managed by improved analysis and information processing activities. This view is challenged by an alternative interpretation that has emerged from studies in the sociology of innovation: the nature of the innovation is considered chaotic and filled with conflicts and controversies, which can't be reduced or removed by more analysis or better information, but need to be solved from one instance to the next (Latour, 1987; Akrich et al. 2002a). Thus, following the advice of Alvesson and Sandberg (2011) the aim of the present research is not to fill a gap in the prior research, but rather to suggest another problematisation to supplement existing 
knowledge. Therefore, we suggest identifying and analyzing the controversies in the FFE and how these are dealt with.

Thus, the present analysis contributes by investigating the controversies that managers face, how they take account of these by articulating a problematisation, how the company deals with the closing of the controversy and who is involved in that process. We introduce a theoretical framework (Latour, 1987) that can help to analyze the struggles in the FFE. What are the problems, the dilemmas that human and nonhuman actors are presented with? What are the controversies about, and how do the actors make an account of the situation and frame the search for solutions, and how are the controversies closed so the FFE can move on?

The remaining is structured accordingly. First, prior research on the FFE is presented. Second, we derive the analytical framework, and applied constructs with a section on the ethnographic approach. Third, controversies in four cases are analyzed. Finally, a discussion and a conclusion are presented with implications.

\section{PRIOR RESEARCH ON FFE}

Prior research on FFE has focused on information processes. The literature review on past FFE research is organized into those, which focus on uncertainty reduction, and those that focus on information improvement. This distinction on information processing comes from Galbraith (1973).

\section{Improved analysis and information processing and intuition}

Reid and Brentani claim that the FFE 'at its core, is an information processing activity' (2004, p. 71) and derived a theoretical model and identified different types of decisions that need to be made regarding the environment, important individuals and the organization, and later suggest that the decision processes occur primarily at the informal, individual level and are based mostly on tacit and not codified information and knowledge (Reid \& Brentani, 2012).

External collaboration can be a strategy to increase the inflow of solutions and external knowledge, as with open innovation approaches (Chesbrough, 2006; Dahlander \& Gann, 2010; Grönlund, Sjödin \& Frishammar, 2010), but others have found that organizational processes, incentive systems and structure might support open innovation approaches but these are not sufficient to produce success (Christiansen, Gasparin \& Varnes, 2013). 
Using different technologies and methods can increase the speed of problem solving, prototyping and continuous testing (Saff \& Ernst, 2003), or improve the FFE by using information systems and knowledge sharing (Gordon et al., 2008) or knowledge management (Akbar \& Tzokas, 2013).

Lately, the use of intuition to improve decision-making in the FFE has been suggested (Eling, Griffin \& Langerak, 2013). National cultures can influence the search for external information and decision-making styles (Godoe, Vigrestad \& Miller, 2014), and corporate culture and support for communities of practices can be supportive of the FFE (Bertels, Kleinschmidt \& Koen, 2011).

\section{Uncertainty reduction}

Structuring activities to reduce uncertainty have been proposed as a viable approach, and different phase models has been suggested (Murphy \& Kumar, 1997; Frishammar, et al., 2013) while Khurana and Rosenthal (1998) develop an activity and processes model for the front end that through different phases leads to a screening and a Go/No-go decision.

Some suggest that a common language for the FFE is needed for benchmarking between companies and suggest a model or 'engine' with senior management activities to be carried out, but state that in the FFE 'ideas are expected to flow and iterate' as 'they are expected to actually proceed in a more random and non-sequential fashion' (Koen et al., 2001, p. 49). However, studies of radical innovation projects in the pharmaceutical industry claim to find a 'process [is] far from random and unpredictable; rather it is an iterative learning process and has become increasingly project-oriented, using stage-gate models (Aagaard \& Gertsen, 2011, p. 341). Contrarily, others find that knowledge about the actives in the FFE is still rather limited, and that the processes can be characterized as 'iterative trial-anderror processes, in which experiments, environmental scanning, and administrative planning constitute key methods for uncertainty reduction' (Frishammar et al., 2013, p. 213).

The fuzzy front end might be shortened by using cross-project management to improve knowledge generation (McGrath, MacMillan \& Tushman, 1992), with overlapping activities (Smith \& Reinertsen, 1991) or by front-loading and supportive 
organizational structures (Thomke \& Fujimoto, 2000) or integration by a project management office (Artto et al., 2011).

Reducing uncertainty by decreasing complexity in the idea development was found to be critical by Kim \& Wilemon (2003) and different methods to reduce uncertainty have been suggested, such as conducting ethnographic studies (Rosenthal \& Capper, 2006), because this method can identify design opportunities not obvious from the outset, and along the same line of thinking early customer involvement might also reduce the fuzziness (Alam, 2006).

According to some authors intelligent planning and the reduction of technical and market uncertainty explain later success (Verworn, Herstatt, \& Nagahira, 2008) e.g. by using tools to help innovators track and assess front-end fuzziness from different sources (Chang, Chen \& Wey, 2007) and having engaged management attention to reduce uncertainty (Poskela \& Martinsuo, 2009). Uncertainty affects the FFE, therefore early involvement of all departments, planning prior to development, and reducing market and technical uncertainty positively affect product development success (Akbar \& Tzokas, 2013). A contingency argument has been presented; as uncertainty reduction seems to be a viable strategy, especially for incremental innovation, improved analysis and preparation can facilitate a better outcome (Verworn et al., 2008). However, for radical new to the company innovations, planning, preparation and ambiguity might be of a different nature, and call for approaches that deals with the emerging controversies, as they might come from unexpected places.

\section{ANALYTICAL FRAMEWORK}

Differences between studies reporting order and structure in the FFE and those that emphasize the emerging and disordered nature of the FFE might be ascribed to different research approaches. Questionnaires and surveys might not be the best approaches to investigate unordered microprocesses. We therefore suggest a theoretical lens that recognizes unordered microprocesses in non-sequential processes (Latour, 1987) that feed into the more linear development phases (Khurana \& Rosenthal, 1998). We want to study things in the making by a retrospective analysis of controversies in the FFE and how these controversies are closed. This is a new approach to understanding the processes in the FFE. The analytical constructs are 
derived from the actor-network theory that claims to be able to unveil 'science and technology in the making' (Latour, 1987).

The FFE is in this perspective seen as a series of non-sequential actions, not a priori constituted, not ordered by a phase model, but actions initiated to solve controversies which help move the FFE from the solution of one controversy to the next one (Latour, 1987). The analysis focuses on controversies, taking account of the situation (framing of the problem), the search for solutions, human and non-human actors involved in the search and in the closing of the controversy. Examples of nonhuman actors can bee materials, production devices or patents.

Controversies represent a dilemma, a conflict, a disagreement, an ambiguity about where to go to solve a problem and how to solve it, and a challenge (Latour, 2005), and require actors to take actions to settle them, which often becomes a kind of collective process (Latour, 1987) that involves searches for solutions and negotiations.

Controversy is a widely used concept in ANT, which is often not defined. Latour (1987) mentions five times that ANT should study, follow and open up controversies but with no definition and the term is mentioned 104 times in Latour (2005) without definition.

Controversies have been studied in Science and Technology Studies with respect to a broad range of different issues, as mentioned in the overview by Martin and Richards (1995) on "scientific and public controversies over scientific and technical issues" (Martin and Richards, 1995: 506). Examples of studies of scientific controversies are the control of AIDS, the proposed introduction of the "abortion pill," about whether "cold fusion" exists, the location of an airport, the implications of the "greenhouse effect or whether fluoride should be added to public water supplies" (Martin and Richards, 1995). Recent examples are studies of geography (Whatmore, 2009) and accounting (Alcouffe, Berland, \& Levant, 2008).

We don't have knowledge of studies that explicitly define themselves as focusing on controversies in the FFE. But what are controversies as studied from an ANT view? The most extensive discussion about controversies is found in Elzinga and Brante (1990: 36-37):

"Controversus [original italics] is a Latin term and means "turned in an opposite direction". More specifically, the definition often focuses on "the clash of opposing opinions; debate; disputation. Controversy creates interaction; thus it signifies unifying as well as divergent 
tendencies between groups of antagonists. Rough synonyms are conflict or contradiction".

Controversies has certain endurance in time and space (Ibid.: p. 36) and thus is not easily solved or removed. It is a manifest contradiction (ibid. p. 37) so it's visible and recognized as a challenge. Thus, the meaning of 'controversy' departs from a view on processes with conflicts, struggles, disagreement and conflicting interests and objectives.

Brante and Elzinga (1990) discuss controversies as "theoretical and empirical critique"; debates on "negative effects"; "conflicts" related to different stakeholder interests and perceptions; "disputes" as opposed to consensus; a "political power struggle", and addresses controversies as part of a "brutal warfare" between stakeholders.

A protocol to study controversies was designed by Markle and Petersen in 1981. The protocol begins with identifying the controversy by asking about the origins of the "challenge" and where the challenge came from and so on (Markle and Petersen, 1981: 28). As the protocol addresses the issue from multiple points of departure, it's open for many different types of challenges.

More recently the mapping of controversies has lead to small and large projects using a cartographic approach (Venturini, 2009), e.g. though the Macospol project (2007:6) that defines the public controversies which that project analyzes, as

" "[...] controversy" refers here to every bit of science and technology which is not yet stabilized, closed or "black boxed"".

Five characteristics of controversies are mentioned: controversies involve all kind of actors (human and non-humans); controversies display the social in its most dynamic form; controversies are reduction-resistant (We need to investigate and understand the micro-processes.); controversies are conflicts (There are uncertainty and disagreement involved) (Venturini, 2009: 261-262).

Moving from controversies in science to innovation, Callon (1981: 384) defines controversies around the development of an electric car in France (Vel), and states that there are four elements in a controversy (our translation from French): 
1. It relates to a technical object (VEL) (But is not solely a technical issue); 2. the solutions are multiple; 3 . the social groups involved and their interests are as numerous and varied as possible; (...) everyone defends specific interests, subject to negotiations; 4. the opposing forces throughout the controversy balance at all times.

Callon (1989), also referring to the VEL case, recognizes the impossibility of distinguishing phases or activities that are distinctly technical or scientific from others that are guided by an economic or commercial logic during the innovation process., The analysis of the controversies regarding the development of a radical new method for fishing scallops involved studying both human and non-human actors (Callon, 1989).

In the present study, the term controversy is used to identify highly uncertain situations, unclear on how to proceed, unsure on which solutions seem to be needed and available, and which could be the future provisions of how the project could develop based on the choices that are made. Controversy provides insights into central struggles in the FFE and it is defined as a " force fields" (Whatmore, 2009) that reveals the contradictions in the FFE and how they are managed. To stabilize - close a controversy, human and non-human actors need to agree that the identified solution is acceptable and stable enough so the FFE can move to the next issue. Analyzing controversies thus becomes an analytical focus here, based on the assumption of the fragile and non-stable FFE in a world filled with constant negotiations because,

[...], ANT claims that we will find a much more scientific way of building the social world if we abstain from interrupting the flood of controversies. (Latour, 2005, p. 24)

With this theoretical lens, each innovation and FFE process can only be stabilized when a sufficient number of allies agree to move in the same direction.

It is not simply a question of the number of allies but of their acting as a unified whole (Latour, 1987, p 131).

The controversy forces the propelling actor, e.g. a manager, called the spokesperson (Akrich, Callon and Latour, 2002b) - to make an account of the situation, initiate or stimulate support, and take action in order to move the process onward. 
Making account of the situation is the second analytical concept used in the analysis. The account of the situation is an analytical term originated by Garfinkel (1967) and recently discussed in research on accounts and accountabilities (Woolgar \& Neyland, 2013). Accounts are stories, narratives, constructs, and codes that are recognizable by others and make sense for members of a community or organization, without further explanations (Garfinkel, 1967).

Any setting organizes its activities to make its properties as an organized environment of practical activities detectable, countable, recordable, reportable, tell-a-story-about-able, analyzable — in short accountable. (Garfinkel, 1967, p. 33)

When actors actively make an account of the situation they identify, frame and communicate the interpretation of the situation and what the controversy is about. This provides guidelines for action and directs attention of involved actors. This - if successful - leads to the alignment of actors and their activities so the controversy can be dealt with and, hopefully, resolved so the FFE can continue, being successful ended or stopped.

The search for a solution identifies the activities that are carried out in order to solve the controversy and how the actors are mobilized (Latour, 1987).

Human and non-human actors involved in the search for solutions are those who are active in the search for solutions to the controversy. Human and non-human actors in ANT are considered equally important and relevant and this makes it possible for the analysis to also include how, for example, materials and technologies play a role in the FFE (Latour, 1987, 2005).

An actor in ANT is a semiotic definition - an actant - that is something that acts or to which activity is granted by another ... an actant can literally be anything provided it is granted to be the source of action (Latour 1996, p. 373).

The closing of controversies represents the processes whereby an unstable situation is stabilized, human and non-human actors aligned and an acceptable solution is identified, so the FFE process can move on. The closing of controversies can be temporary if the FFE includes more controversies, or of a more permanent nature so 
the whole FFE can be closed, making it possible to move the innovation process from the FFE to the next steps in the innovation process (Khurana \& Rosenthal, 1998). The controversies are closed when the actors agree on the solution proposed, the solution is stable and there is no further discussion; they accept and work together to make it work (Latour, 1987).

Studying controversies provides an alternative view on the FFE, and this can be useful as each theory and method seems to generate "their own facts" (Brante \& Elzinga, 1990). Alternative theories can provide new insights. Investigating controversies can be a fruitful approach to understand what types of decisions managers have to deal with, by investigation of actual cases, rather than relaying on ex post data from surveys. Finally, controversies throw some light on the needed skills in the FFE and might provide insights on what areas should be explored by further studies.

\section{METHOD}

Ethnographic studies require the researcher to uncover actors (humans and nonhumans) in a process of constant investigation into their relationships, collecting suggested interpretations, controversies, sources of mobilization, by 'following the actors in their network construction' (Latour, 2005). So, any accounts of observed practices are not considered 'final' or closed for further investigation. They are considered preliminary, and they spur the next investigation, as there is always the possibility of further questioning (Garfinkel, 1967), as demonstrated in previous ANT research (Latour, 1999. 2005).

Based on prior contacts with the company, and after meetings and negotiations with senior management, access was granted for three researchers to the company museum, which contains prototypes and products, company documents, such as the minutes from board meetings, scrapbooks, leaflets and marketing material. A steering committee, with two managers from the company, met the researchers every 4-6 months over a period of 2 years. One of the three researchers was the prime investigator and spent a total of more than 60 days with the company. During the weekly site visits, formal and informal ad hoc interviews were conducted. Additional background information was collected from recorded radio, television documentaries, and documents collected in the Design Museum in Copenhagen, the Victoria and Albert Museum in London, and Catherine College in Oxford. The material was 
ordered into a database, which subsequently consisted of 65 images from public museums, 563 records related to the four analyzed chairs and their design, 1,219 images from the collection in the company museum and 246 records concerning different internal documents, including reports, letters, minutes, financial documents, financial statements, press releases and clips from newspapers and magazines and presentations. For each record, details on the source, content and other signifiers were noted in the database.

Three rounds of scheduled interviews were conducted. To guide the interviews, a list of questions was prepared and reviewed by three researchers, functioning as a checklist (Kvale \& Brinkmann, 2009). The 22 scheduled interviews lasted between 1 hour and 2.5 hours, were transcribed, coded and analyzed using Dedoose. Five of the interviewees were interviewed twice.

\begin{tabular}{|c|c|c|c|c|c|}
\hline Date & Position & Function & Date & Position & Function \\
\hline June 2011 & Design manger & Architect & Nov 2011 & FH designer & Cabinetmaker \\
\hline June 2011 & FH designer & Cabinetmaker & Nov 2011 & $\begin{array}{l}\text { Librarian at } \\
\text { Design museum }\end{array}$ & Historian \\
\hline June 2011 & $\begin{array}{l}\text { Consultant at the } \\
\text { DK Design Centre }\end{array}$ & Historian & Sep 2012 & HR manager & Business \\
\hline June 2011 & Large design shop & & Oct 2012 & $\mathrm{CFO}$ & Finance \\
\hline June 2011 & Brand Manager & Marketing & Oct 2012 & $\begin{array}{l}\text { Former design } \\
\text { manager }\end{array}$ & Architect \\
\hline June 2011 & Head of Design & Architect & Oct 2012 & $\begin{array}{l}\text { Marketing } \\
\text { manager }\end{array}$ & Marketing \\
\hline June 2011 & Graphic Design & Design & Oct 2012 & Design manager & Architect \\
\hline June 2011 & Brand Operations & Business & Feb 2013 & $\begin{array}{l}\text { Librarian at St. } \\
\text { Catherine Coll. }\end{array}$ & Archeologist \\
\hline July 2011 & Kasper Salto & Designer & March 2013 & Design manager & Architect \\
\hline July 2011 & $\begin{array}{l}\text { Mgr. auction house } \\
\text { in Milano }\end{array}$ & Historian of Art & March 2013 & $\begin{array}{l}\text { Marketing } \\
\text { manager }\end{array}$ & Business \\
\hline Oct. 2011 & $\begin{array}{l}\text { Personal Assistant } \\
\text { to the CEO }\end{array}$ & Engineering & March 2013 & $\mathrm{CFO}$ & Finance \\
\hline
\end{tabular}

Table 1: The 22 scheduled interviews.

Besides the scheduled ones, more than 25 informal interviews were made with employees encountered during lunchtime, visits to different departments and in the car park. These interviews were not recorded, but were included into the database in written form, based on the notes that the primary researcher wrote after the interaction. 
The data were analyzed by going through three cycles of coding. The first cycle, based on the motto 'follow the actors in the network construction' (Latour, 2005), included classifying actors into different groups and these were exported into spreadsheets, used to analyze associations between actors, among other things.

The second cycle of coding was aimed at coding the controversies and solutions, because:

ANT furnishes us with the tools to better attend to the minute displacements, translations, practices, riots, processes, protests, arguments, expeditions, struggles, and swap-meets - no matter what the actors involved may look like. (Sayes, 2014 p. 145)

Later, controversies were subsequently related to the account-making, and search and closing processes for each controversy were identified from the data by additional coding of the material made independently by the two researchers.

This approach was based on three methodological principles: agnosticism, generalized symmetry and free association. Agnosticism implies abandoning any preconceived assumptions of causal relationships, nature of the networks or the accuracy of the actor's explanations, because all interpretations have equal importance (Ritzer, 2005). Generalized symmetry implies not changing registers when researchers move from the technical to the social aspects (Callon, 1986), using the same explanatory frame or vocabulary to examine human and non-human actors (Ritzer, 2005). Free association requires that the observer abandon the division between the social and the technical in the analysis.

The study observes criteria of validity, reliability and generalization. Reliability was achieved by filing all collected data, both primary and secondary, in a database accessible for all researchers in the study. Internal validity, as concerned with the soundness and rigor of the study (Daymon \& Holloway, 2011, was achieved by multiple presentations and discussions of the analytical framework. Furthermore validity was achieved by using the 'member checking' method, which requires the researchers to present the analysis and the results to the participants in the study and listen carefully to their feedback (Daymon \& Holloway, 2011). 


\section{ANALYSIS}

The four products selected for analysis were strategically chosen (Kvale and Brinkman, 2009, p. 264). Cases are "stratified purposeful cases" as they were considered critical and being radical innovations by the company and also represented different innovation approaches (Patton, 1990). By this strategy cases could provide a rich variation in observations (Kvale and Brinkman, 2009; Patton, 1990) with respect to different types of controversies. Furthermore, cases where considered significant and critical (Patton, 1990). The cases chosen are four different chairs developed and manufactured by the Fritz Hansen Company. 'Series 7' was launched in the marketplace in 1955, 'Egg' in 1958, 'Ice' in 2002 and 'Ro' in 2013. They also represented variations in the types of contributions for the company: a new design and new production techniques (Series 7, Egg); radical rebranding but incremental product (Ice); new development and manufacturing process (Ro).

The Series 7 is a plywood chair designed by Arne Jacobsen, manufactured by the family-owned company Fritz Hansen (founded in 1872), introduced to the market in 1955 and claimed to be the most sold chair in the world. This chair was new, simple, modest, but at the same time expressive and represented a radically new design (Christiansen et al., 2010). New manufacturing techniques were required, developed from existing skills: Søren Hansen, one of the two top managers and one of three brothers involved in the company at that time, was searching for new designs and manufacturing techniques. Well-established handcraft companies were experiencing difficult times in Europe and the management in the company Fritz Hansen wanted to develop an industrial production and initiate new radical designs. The company engaged with the successful architect Arne Jacobsen, who was searching for a new chair for a large contract he had just been given, and Fritz Hansen suggested he develop a new chair using a technique developed by Charles and Ray Eames and Eero Saarinen, based on plywood. The hot-steam technology for bending wood, already available in the company, was refined for the bending of plywood. After many experiments, manufacturing successfully stabilized the shape of the prototype without having to modify the thickness of the plywood. Arne Jacobsen worked intensively on the design with Søren Hansen and the manufacturing team for more than a year, and the result was achieved by pressuring one piece of 10 thin layers of veneer to form the seat and the back, and that plywood was attached to three slender metal legs with 
rubber feet. The outcome was a chair called 'Ant', which received very positive and enthusiastic reviews in newspapers and by architects, but private customers did not like the three legs and the lack of armrests. Arne Jacobsen, together with Søren Hansen and Fritz Hansen, after some time decided not to modify the Ant chair, but to design a new chair, which was meant to be ergonomic, organic, and functional with four legs and armrests, closing the controversy.

\begin{tabular}{|c|c|c|c|c|}
\hline \multicolumn{5}{|c|}{ Series 7 chair } \\
\hline & Profit & Production & Design & Customers \\
\hline Controversy & Cost concerns & $\begin{array}{l}\text { Industrial steam- } \\
\text { bending } \\
\text { techniques }\end{array}$ & $\begin{array}{l}\text { Creative design } \\
\text { alternatives }\end{array}$ & $\begin{array}{l}\text { Complaints about } \\
\text { stability of first } \\
\text { model }\end{array}$ \\
\hline $\begin{array}{l}\text { Account of } \\
\text { situation }\end{array}$ & $\begin{array}{l}\text { Industrial } \\
\text { production needed }\end{array}$ & $\begin{array}{l}\text { Invest in new } \\
\text { production } \\
\text { facilities }\end{array}$ & $\begin{array}{l}\text { Design team } \\
\text { encouraged to } \\
\text { develop rapid } \\
\text { prototypes }\end{array}$ & Improved design \\
\hline Search & $\begin{array}{l}\text { New production } \\
\text { methods }\end{array}$ & $\begin{array}{l}\text { Financial } \\
\text { alternatives }\end{array}$ & $\begin{array}{l}\text { Prototypes from } \\
\text { design team }\end{array}$ & $\begin{array}{l}\text { A different chair - } \\
\text { or a modified } \\
\text { chair? }\end{array}$ \\
\hline Human actors & $\begin{array}{l}\text { Two senior } \\
\text { managers } \\
\text { (owners) }\end{array}$ & $\begin{array}{l}\text { Manufacturing } \\
\text { and engineering } \\
\text { employees }\end{array}$ & $\begin{array}{l}\text { Designer, } \\
\text { blacksmiths, } \\
\text { wood-engineering, } \\
\text { management }\end{array}$ & $\begin{array}{l}\text { Designer, owners, } \\
\text { design team }\end{array}$ \\
\hline $\begin{array}{l}\text { Non-human } \\
\text { actors }\end{array}$ & $\begin{array}{l}\text { Craft production } \\
\text { facilities }\end{array}$ & $\begin{array}{l}\text { Banks, equipment, } \\
\text { test production }\end{array}$ & $\begin{array}{l}\text { Prototypes, new } \\
\text { production options }\end{array}$ & Existing chairs \\
\hline $\begin{array}{l}\text { Closing of } \\
\text { controversy }\end{array}$ & $\begin{array}{l}\text { Identify potential } \\
\text { solutions in the } \\
\text { USA }\end{array}$ & $\begin{array}{l}\text { New production } \\
\text { facilities }\end{array}$ & $\begin{array}{l}\text { First version of } \\
\text { chair in } \\
\text { production }\end{array}$ & $\begin{array}{l}\text { Modified chair } \\
\text { prototype of the }\end{array}$ \\
\hline & & & & Series 7 ready \\
\hline
\end{tabular}

Table 2: Controversies in the FFE for the Series 7 chair.

The CEO, Søren Fritz Hansen, realized the opportunity and propelled the process for creating this new radical product. He started to pursue the vision of developing the business model towards industrial production rather than staying an advanced workshop and cabinetmaker. He saw the opportunities for growth having an industrial production based on plywood, he supported design alternatives, translated customer complaints, and stimulated the work of the designer Arne Jacobsen and alternative 
design processes; he facilitated the design process by communicating across the different functional divisions (mainly design and manufacturing). The CEO in this case was actively participating in many processes, and these many roles are surprisingly broad and interactive: interpreting the situation, searching for solutions, and taking actions to close the controversies.

The Egg is a lounge - or easy - chair made of foam flake composites, covered by fabric or leather and supported by an aluminum foot, originally designed and presented as part of the interior for the Copenhagen Royal Hotel, and later made available for private customers. The CEO Søren Hansen agreed on supporting the development process, because of the large order that the hotel had requested, which meant it could be designed for industrial production. The shell of the chair is made of polystyrene, known as Styropor, used for military purposes during the Second World War. After the war, the designers Eames and Saarinen picked up the material, using it in furniture, which was noticed by Søren Hansen in New York, and he brought samples to Denmark. Once Jacobsen and Hansen agreed to start the design process for a chair made of that material, the company Fritz Hansen acquired a license to use the polystyrene material. Arne Jacobsen began sketching two chairs - later known as the Egg and the Swan -- and he distributed the proposals among those involved in his design studio and to Søren Hansen. After the sketches, Arne Jacobsen began working on developing prototypes, and these were used in the dialogue between him and the manufacturer. The first prototypes were modeled in plasticine, followed later by another version in full-size plaster. Later, the teams from Fritz Hansen and Arne Jacobsen's design studio worked with a shipbuilder to mould a hull, which was filled with foam flakes to produce the desired shape. Simultaneously with the design experiments, the CEOs of Fritz Hansen, Søren Hansen and Fritz Hansen, acquired the necessary machinery and worked on training laborers in the factory. Søren Hansen and Fritz Hansen were in charge of closing the controversy. 


\begin{tabular}{|c|c|c|c|c|}
\hline \multicolumn{5}{|c|}{ The Egg chair } \\
\hline & Profit & Production & Design & Customers \\
\hline Controversy & $\begin{array}{l}\text { Cost and market } \\
\text { concerns }\end{array}$ & New skills needed & Using new skills & $\begin{array}{l}\text { Economic upturn } \\
\text { and looking for } \\
\text { modern furniture }\end{array}$ \\
\hline $\begin{array}{l}\text { Account of } \\
\text { situation }\end{array}$ & $\begin{array}{l}\text { Industrial } \\
\text { production } \\
\text { needed }\end{array}$ & $\begin{array}{l}\text { Difficult to } \\
\text { control shaping }\end{array}$ & $\begin{array}{l}\text { Need for rapid } \\
\text { prototypes }\end{array}$ & $\begin{array}{l}\text { Design should be } \\
\text { modern and } \\
\text { suitable for small } \\
\text { spaces }\end{array}$ \\
\hline Search & $\begin{array}{l}\text { New production } \\
\text { methods }\end{array}$ & $\begin{array}{l}\text { Production } \\
\text { alternatives }\end{array}$ & $\begin{array}{l}\text { Stimulate design } \\
\text { team }\end{array}$ & $\begin{array}{l}\text { Mould the } \\
\text { plasticine and } \\
\text { keep design } \\
\text { lightweight? }\end{array}$ \\
\hline Human actors & $\begin{array}{l}\text { Two owners and a } \\
\text { designer }\end{array}$ & $\begin{array}{l}\text { Manufacturing } \\
\text { and engineering }\end{array}$ & $\begin{array}{l}\text { Designer, } \\
\text { blacksmiths, } \\
\text { outside plastic } \\
\text { engineers, } \\
\text { management }\end{array}$ & $\begin{array}{l}\text { Designer, owners, } \\
\text { design team }\end{array}$ \\
\hline $\begin{array}{l}\text { Non-human } \\
\text { actors }\end{array}$ & Styropor patent & $\begin{array}{l}\text { Hull, equipment, } \\
\text { test production }\end{array}$ & $\begin{array}{l}\text { Prototypes, new } \\
\text { production } \\
\text { options }\end{array}$ & $\begin{array}{l}\text { Plasticine model, } \\
\text { moulding } \\
\text { techniques, } \\
\text { previous chairs }\end{array}$ \\
\hline $\begin{array}{l}\text { Closing of } \\
\text { controversy }\end{array}$ & $\begin{array}{l}\text { Collection of } \\
\text { potential solutions }\end{array}$ & $\begin{array}{l}\text { New production } \\
\text { skills developed }\end{array}$ & $\begin{array}{l}\text { First version of } \\
\text { chair realized } \\
\text { with plasticine }\end{array}$ & $\begin{array}{l}\text { A hull able to } \\
\text { realize the } \\
\text { plasticine chair } \\
\text { design }\end{array}$ \\
\hline
\end{tabular}

Table 3: Controversies in the FFE for the Egg chair.

Again the CEO, Søren Fritz Hansen, facilitated the process for creating this new radical product based on his personal experience after seeing what could be done with the new material in the USA. He successfully enrolled the designer and the material (with a license to use it) in the FFE processes, which was closed when the iconic design of the Egg was successfully moulded with the help of a sculptor and a shipbuilder, among others. The search processes included being open to new materials, acquiring a license, developing manufacturing skills and equipment, and a search for the ultimate sculptural furniture.

The Ice chair marks a change in usability of furniture's from the firm, as it was the first chair equally suited for both indoor and outdoor use marketed by Fritz Hansen; lightweight, made of natural anodized aluminum and of ASA-plastic, a sturdy and 
sustainable choice. The Ice chair had a long fuzzy front end. The designer Kasper Salto worked on the design from August 1997 to October 2002. At the beginning, the majority of the meetings were with the design management team in Fritz Hansen, but often with only the design manager and the CEO, translating the design brief created on the premise of market research conducted by the marketing department, into a design proposal.

The design brief was regarded an important tool for the management of the fuzzy front end by top management, who invited four teams to a competition, without revealing they were in a competition for creating prototypes.

At the individual meetings with the designers, the CEO and the managers discussed the brief. Kasper Salto affirmed that he wanted to incorporate the Fritz Hansen cafe chair, which had gone out of production some years before, as an inspirational chair to be mobilized during the sketch phase. The top management team in FH developed the brief, or rather added more requirements to it: requiring a product that could be located and travel everywhere, in all environments of the house, in different buildings, and also outside. For the designers, it was a very ambitious project, and very hard to solve. The risk was high, since the chair could be interpreted as a chair that was suitable for all and nothing.

The competition, which involved having simultaneous conversations and processes with multiple designers, was kept secret from the designers involved for two years. Finally, all those designers involved were informed about the competition and rushed to finalize their prototype. When the final prototypes were presented, Kasper Salto was declared the winner, while Jacob Holm, the CEO, asked if the design could be upscaled by $4-5 \%$ compared to the first prototype, and after this the design was finally frozen and all FFE controversies closed. 


\begin{tabular}{|c|c|c|c|}
\hline \multicolumn{4}{|c|}{ Ice chair } \\
\hline & Brand & Design & Customers \\
\hline Controversy & Brand concerns & $\begin{array}{l}\text { Production of design } \\
\text { alternatives }\end{array}$ & $\begin{array}{l}\text { Versatile chair and } \\
\text { appropriate size }\end{array}$ \\
\hline Account of situation & $\begin{array}{l}\text { Re-launch of Fritz } \\
\text { Hansen as the } \\
\text { Republic of Fritz } \\
\text { Hansen }\end{array}$ & $\begin{array}{l}\text { Produce design brief } \\
\text { for designers }\end{array}$ & $\begin{array}{l}\text { Design suitable for } \\
\text { both indoor and } \\
\text { outdoor use and also } \\
\text { for meeting rooms }\end{array}$ \\
\hline Search & $\begin{array}{l}\text { New material } \\
\text { /production methods }\end{array}$ & $\begin{array}{l}\text { Generate prototypes } \\
\text { from designers }\end{array}$ & Select design and size \\
\hline Human actors & $\begin{array}{l}\text { CEO and design } \\
\text { manager }\end{array}$ & $\begin{array}{l}\text { Designers, assistants } \\
\text { from production, } \\
\text { design and marketing } \\
\text { manager }\end{array}$ & $\begin{array}{l}\text { Designer, marketing, } \\
\text { CEO, design manager, }\end{array}$ \\
\hline Non-human actors & Plastic material & $\begin{array}{l}\text { Design brief, design } \\
\text { workshops, proposals }\end{array}$ & Existing prototype \\
\hline $\begin{array}{l}\text { Closing of } \\
\text { controversy }\end{array}$ & $\begin{array}{l}\text { Identify potential } \\
\text { designers and create } \\
\text { competition }\end{array}$ & $\begin{array}{l}\text { Select wining designer } \\
\text { and design }\end{array}$ & $\begin{array}{l}\text { Modified version of } \\
\text { the prototype }\end{array}$ \\
\hline
\end{tabular}

Table 4: Controversies in the FFE for the Ice chair.

Once again, with a new CEO and the company design manager, senior management was driving the process for creating this new product design to revitalize the company's brand, moving from Fritz Hansen to 'the Republic of Fritz Hansen'. The management developed a new process for involving designers, stimulating their creativity, and communicating across the different actors (design and design manager). The CEO in the Ice case actively participated in many processes; developing the first design brief, interpreting the situation, participate in the selection of designers to be invited, taking account of alternatives, proposing solutions and additions to the design brief and selecting the winning design. 
The Ro chair is a so-called easy chair, intended to be a comfortable and relaxing chair and was brought to market in 2013. The ambition of the company was to introduce a newly designed easy chair with a lower price tag than the already existing Egg. The FFE process started with a deliberately interactive and iterative design process that was new to those involved in it. In previous years, a sequential linear gate model had been applied to all new design processes, but with this project the company wanted to do something different and more interactive. The overall design process was done inhouse, inviting employees from different departments to participate in the process, starting by sketching ideas for the design brief, and also consulting them during the last phases of the prototype, in which some provided suggestions for the back seat.

The senior management upfront decided to use the external designer Jamie Hayón, because of a prior successful collaboration. After the designer received the design brief he presented some drawings, some rough sketches and concept suggestions based on it. Afterwards, the design manager, the CEO, the CFO and the marketing manager selected two concepts they considered interesting. The management also had meetings to discuss alternative scenarios, looking at the current product portfolio and the targeted market needs. The selected model evolved into multiple models and sketches, which led to different prototypes, in order to understand how a certain design might look in real scale, while none of them were completed. They were built with the aim of visualizing possible outcomes.

The designer affirmed that Fritz Hansen is known in the design community as being among the best in producing upholstered chairs, so he decided to challenge the team by making the manufacturing of the shell difficult; this he did by designing it to go from the back inside out in a circular shape. Jamie Hayón and the employees from manufacturing worked very closely: the designer drew and proposed models, the manufacturing employees worked with him to adjust the prototype of the shell according to the changes, contributing by commenting on the design and suggesting improvements for solving the challenges related to the manufacturability. 


\begin{tabular}{|c|c|c|c|}
\hline \multicolumn{4}{|c|}{ Ro chair } \\
\hline & Profit & Design & Customers \\
\hline Controversy & $\begin{array}{l}\text { Cost and brand } \\
\text { concerns }\end{array}$ & $\begin{array}{l}\text { Production of design } \\
\text { alternatives }\end{array}$ & $\begin{array}{l}\text { Looking for cheaper } \\
\text { and modern easy chair }\end{array}$ \\
\hline Account of situation & $\begin{array}{l}\text { Create an new } \\
\text { affordable easy chair } \\
\text { made of Styropor }\end{array}$ & $\begin{array}{l}\text { Design team } \\
\text { encouraged to develop } \\
\text { rapid prototypes }\end{array}$ & $\begin{array}{l}\text { Fresh look and lower } \\
\text { production costs }\end{array}$ \\
\hline Search & $\begin{array}{l}\text { Look for designer that } \\
\text { wants to collaborate } \\
\text { and work from the } \\
\text { design brief }\end{array}$ & $\begin{array}{l}\text { Prototypes from } \\
\text { design team }\end{array}$ & $\begin{array}{l}\text { Proposing a modern } \\
\text { furniture also for } \\
\text { young (new) } \\
\text { customers }\end{array}$ \\
\hline Human actors & $\begin{array}{l}\text { CEO, design manager, } \\
\text { marketing manager, } \\
\text { CFO }\end{array}$ & $\begin{array}{l}\text { Designer, } \\
\text { blacksmiths, Styropor, } \\
\text { engineering, } \\
\text { management }\end{array}$ & $\begin{array}{l}\text { Designer, owners, } \\
\text { design team }\end{array}$ \\
\hline Non-human actors & Styropor & $\begin{array}{l}\text { Prototypes, new } \\
\text { solutions to mould the } \\
\text { Styropor }\end{array}$ & Prototypes, Egg chair \\
\hline $\begin{array}{l}\text { Closing of } \\
\text { controversy }\end{array}$ & Identify designer & First prototype & $\begin{array}{l}\text { Prototype with a } \\
\text { modern egg shape }\end{array}$ \\
\hline
\end{tabular}

Table 5: Controversies in the FFE for the Ro lounge chair.

After 8 months of iterations, testing, modifications, sketches, prototypes and debates the senior management of the company approved the design of the prototype and the project was handed over to product development, followed by manufacturing, marketing, sales and finally its launch.

Once again, the CEO with the design manager and - somewhat surprisingly for some, maybe - the CFO were the driving force in the process for creating this new easy chair, based on a new design approach. The process was ignited based on customer needs, and stimulated the work of a selected designer to apply a new design approach based on rapid prototyping and close collaboration with the manufacturing team during the FFE - actually going back to the more interactive processes from the Series 7 and the Egg chair cases, rather than the more formalized and distant management attitude in the Ice chair case. 


\section{DISCUSSION}

The analytical framework has made possible for us to map and understand how controversies and dealing with them can produce new insights into the FFE. We contribute to prior research on the processes in the FFE by adding the notion of controversy. Prior studies on the FFE that have mainly focused on decision-making (Reid \& Brentani, 2004) and uncertainty reduction (Kim \& Wilemon, 2003). The presented analysis of controversies - especially for the three radical FFE's -casts some light on what directs the attention of actors: the struggles for closing the controversies represent a stepwise attempt to deal with what is required from the situation, rather than executing a careful pre-made laid plan.

In previous research, the human and non-human actors have been studied separately and the emphasis has been on the role of the gatekeepers, on the environment or organizational issues (Khurana \& Rosenthal, 1998; Veryzer, 1998; Poskela \& Martinsuo, 2009; Martinsuo \& Poskela, 2011) rather than on the controversies, debates and struggles involving human and non-human actors.

The analysis shows a great diversity in the type of controversies that emerge in each of the four processes. The controversies relate to cost and profit concerns, new production techniques, the need for new products and design, brand concerns and feedback from markets and customers. Furthermore, the emerging nature of the radical FFE processes is confirmed (Veryzer, 1998).

Holzer (2012) has shown how a crisis in innovation facilitates an open debate of the situation, but has not been explored in relationship to FFE. The process of taking account of the situation by management is found to be an important activity, as it guides and frames the actions taken to solve the controversy. In the cases, the process of taking account of the situation includes not only searching for information (as already demonstrated by Brentani \& Reid, 2012), but also activities aimed to a trialand-error processes. The searches identified here are contingent and varied: investigating new materials, searching for potential designers, setting up experiments in manufacturing, initiating design sketches and prototypes, searching for financing, interacting with marketing and listening to customer complaints, stimulating design 
teams and evaluating proposals.

Prior studies on FFE seem to be divided between those that have identified some overall kind of structure and phases, especially in radical FFE (Aagaard \& Gertsen, 2011) and others who find that the processes are of an emerging nature, characterized by trial-and-error processes but with some administrative planning (Veryzer, 1998; Frishammar et al., 2013). The analysis here shows that only for the incremental product (Ice chair) was there an overall plan and structure set up for the innovation process, while the other three were of an emerging and exploratory nature, with no clear plan from the outset.

Finally, the interactive and many-faceted roles of senior management in the FFE, especially for the three radical processes, seems to confirm previous studies, regarding the importance of a driver, or 'product champion or visionary' (Veryzer, 1998), or a spokesperson (Akrich, Callon \& Latour, 2202b). Furthermore, the observations that FFE processes are emerging and focused on putting out fires, rather than executing plans (Kurkkio, Frishammar, \& Lichtenthaler, 2012) seems to be confirmed. In order to close controversies, the senior managers were involved in developing the business model, and worked to comprehend production techniques and materials, acquire financial support, ignite design alternatives, translate customer complaints, frame and stimulate design processes and designers, communicate across the different functional divisions in the company, and to participate in the decisionmaking processes. These many roles are surprisingly broad and varied and interactive. The CEOs seemed to be equally important as interpreter of the situation, taking account of the situations, framing the processes and proposing solutions.

Are there different processes for radical innovation and incremental innovation? Radical (or discontinuous) innovation refers to an innovation that involves dramatic leaps in terms of customer familiarity and use (Veryzer, 1998). The products analyzed here were considered radical innovations in terms of material (Series 7 and the Egg), innovation process (Ro) and incremental (Ice). The controversies seemed to start from different places: brand controversies for the incremental product, based on accurate market research, while concerns about profit, market development and cost of production initiated the search for solutions in the radical products. Using the concept 
of controversy, one could re-interpret the findings from previous FFE studies. For example, additional types of controversies might concern production involvement (Kurkkio, Frishammar, Lichtenthaler, 2012); developing IT tools (Gordon et al., 2008); and risk management and legal issues (Frishammar et al., 2013).

\section{Implications and limitations}

The present study has not identified a clear division for context (environment) and the company process and the innovation projects or clearly identifiable decision-making interfaces (Brentani \& Reid, 2012), rather we see blurred boundaries between what's in and what's out. The present analysis reveals processes that go back and forth between 'in- and outside', and rather than boundary spanning we see interaction and cross-fertilization. Among the managerial implications is the call for skills that provide the necessary flexible and integrative approaches that are needed to deal with controversies that emerge from different areas. Could identification and mapping of emerging controversies be used as a method that replaces focus on prediction and planning?

Secondly, the concept of controversies accepts conflicts and dilemmas as paert of the FFE. Instead of reducing uncertainty, improving analysis or computational devices, there is a need to improve the abilities to deal with complexity (Nobelius, \& Trygg, 2002) and especially we found that the framework of controversies might be useful for understanding the struggles that are emerging in the FFE.

Thirdly, even if the selected cases might be influenced by the nature of the furniture industry and a small-medium size company, the observations of how the FFE moves from one controversy to the next still seem to provide an alternative account of how to understand the managerial challenges in the FFE. Rip (2012) has suggested that there is a need to understand the dynamics of innovation and especially the contextual factors that determine the direction of innovation journeys. Such an analysis would, according to Rip, require the identification of patterns and structures or spaces, on different levels. His analysis draws on a combination of ANT and institutional theory, but is outside the scope of this study.

Finally, we uses the phrase 'managing' the controversies in the FFE in the title, and some might find that somewhat presumptuous but the analysis here shows how the meaning of management - or the skills needed - changes from one controversy to another, so managing becomes a call for heterogeneous skills and activities that are 
needed to close the controversies. The CEO seems to be equally important as interpreter of the situation, taking account of the situations and framing the processes, stimulating designers and proposing solutions and providing comments on design briefs and prototypes.

In terms of limitation, some have critically argued that ANT is not even a theory and that its contribution might be limited (Whittle \& Spicer, 2008), and the apparently descriptive nature of ANT has also been criticized (Amsterdamska, 1990), originating from its lack of normative claims. However, the attention to the struggles and controversies from a process perspective has provided insights into the FFE from a different perspective that have not been possible with other theoretical frameworks. We don't argue for generalizations based on this study, but rather for illustrative examples that can be further explored.

\section{CONCLUSIONS}

In this paper, we have analyzed the nature of the controversies in the fuzzy front end, one of the most critical phases of the innovation process. Prior analysis on the managerial issues related to the front end processes have focused on how to reduce uncertainty, to improve information processing or how to improve decision-making, but has not analyzed the controversies that emerge during the FFE, and how those involved have taken account of and dealt with these.

The analysis presented here indicates that the FFE processes can - as an alternative perspective - usefully be understood as a series of controversies that emerge from unpredicted areas during the FFE. Furthermore, the analysis shows how management involvement is guided by attention to solving these controversies, but not only as an information-seeker or decision-maker, but having multiple roles. These many roles are surprisingly broad and varied and interactive. The senior managers seem to be equally important as interpreter of the situation, taking account of the situations, framing the processes, seeking financing and new designers, motivating and being involved in experiments and the development of prototypes and suggesting solutions. 


\section{REFERENCES}

Aagaard, A., and Gertsen, F. (2011) Supporting Radical Front End Innovation: Perceived Key Factors of Pharmaceutical Innovation. Creativity and Innovation Management, 20(4), 330-346.

Akbar, H., and Tzokas, N. (2013) An Exploration of New Product Development's Front-End Knowledge Conceptualization Process in Discontinuous Innovations. British Journal of Management, 24(2), 245-263.

Akrich, M., Callon, M. and Latour, B. (2002a) The Key to Success in Innovation Part I: The Art of Interessement. International Journal of Innovation Management, 6(2), 187-206.

Akrich, M., Callon, M. and Latour, B, (2002b) The Key to Success in Innovation part II: The Art of Choosing Good Spokespersons. International Journal of Innovation Management, 6(2), 207-225.

Alcouffe, S., Berland, N., \& Levant, Y. (2008). Actor-networks and the diffusion of management accounting innovations: A comparative study. Management Accounting Research, 19(1), 1-17.

Alam, I. (2006) Removing the Fuzziness from the Fuzzy Front-End of Service Innovations Through Customer Interactions. Industrial Marketing Management, 35(4), 468-480.

Alvesson, A. and Sandberg, S. (2011) Generating Research Questions Through Problematization. Academy of Management Review, 36(2), 247-271.

Amsterdamska, O.(1990) 'Surely You're Joking, Mr Latour!'. Science, Technology, Human Values, 15(4) pp.495-504.

Artto, K., Kulvik, I., Poskela, J. and Turkulainen, V. (2011) The Integrative Role of the Project Management Office in the Front End of Innovation. International Journal of Project Management, 29(4), 408-421.

Bertels, H. M., Kleinschmidt, E. J. and Koen, P. A. (2011) Communities of Practice Versus Organizational Climate: Which One Matters More to Dispersed Collaboration in the Front End of Innovation? Journal of Product Innovation Management, 28(5), 757-772.

Brante, T., \& Elzinga, A. (1990). Towards a theory of scientific controversies. Science Studies, 2, 33-46.

Brentani, U. and Reid, S.E. (2012) The Fuzzy Front-End of Discontinuous Innovation: Insights for Research and Management. Journal of Product Innovation Management, 29(1), 70-87.

Callon, M. (1981) "Pour une sociologie des controverses technologiques," Fundamenta Scientae 2: 381-99. http://books.openedition.org/pressesmines/1196

Callon, M. (1986). The sociology of an actor-network: The case of the electric vehicle. In Callon, M., Law, J. And rip, A. (Eds). Mapping the dynamics of science and technology (pp. 19-34). London, UK.: Macmillan.

Callon, M. (1986) Some Elements of a Sociology of Translation: Domestication of the Scallops and the Fishermen of St. Brieuc Bay. In Law, J. (ed.), Power, Action and Belief: A New Sociology of Knowledge? Routledge and Kegan Paul, London, UK, pp. 196-233.

Callon, M. (1989) Society in the Making: The Study of Technology as a Tool for Sociological Analysis, in W. E. Bijker, T. P. Hughes and T. Pinch (eds) The 
Social Construction of Technological Systems, pp. 83-103. Cambridge, MA: MIT Press.

Chang, S. -L., Chen, C. -Y. and Wey, S. -C. (2007) Conceptualizing, Assessing, and Managing Front-End Fuzziness in Innovation/NPD Projects. R\&D Management, $37(5), 469-478$.

Chesbrough, H.W. (2006) The Era of Open Innovation, MIT Sloan Management Review, 127(3), 34-41.

Christiansen, J.K., Varnes, C.J., Gasparin, M., Storm-Nielsen, D. and Vinther, E.J. (2010) Living Twice: How a Product Goes through Multiple Life Cycles. Journal of Product Innovation Management, 27(6), 797-827.

Christiansen, J.K., Gasparin, M. and Varnes, C.J. (2013) Improving Design with Open Innovation: A Flexible Management Technology, Research-Technology Management, 56(2), 36-44.

Cooper, R.G. (2008) Perspective: The Stage-Gates Idea-to-Launch Process - Update, What's New, and NexGen Systems. Journal of Product Innovation Management, 25, 213-32.

Dahlander, L. and Gann, D. M. (2010) How Open is Innovation? Research Policy, 39(6), 699-709.

Daymon, C. and Holloway, I. (2011) Qualitative Research Methods in Public Relations and Marketing Communications, Routledge, Oxon.

Eling, K., Griffin, A. and Langerak, F. (2014) Using Intuition in Fuzzy Front-End Decision-Making: A Conceptual Framework. Journal of Product Innovation Management, 31(5), 956-972.

Frishammar, J., Lichtenthaler, U. and Kurkkio, M. (2012) The Front End in NonAssembled Product Development: A Multiple Case Study of Mineral and Metal Firms. Journal of Engineering and Technology Management, 29(4), 468-88.

Frishammar, J., Lichtenthaler, U. and Richtnér, A. (2013) Managing Process Development: Key Issues and Dimensions in the Front End. R\&D Management, 43(3), 213-26.

Galbraith, J. R. (1973) Designing Complex Organizations, Addison-Wesley Pub. Company, Reading, MA.

Garfinkel, H. (1967) Studies in Ethnomethodology. Polity Press, Cambridge..

Godoe, H., Vigrestad, J. and Miller, R. (2014) Fuzzy Front End and Commercialization: Cross-Cultural Differences, Similarities, and Paradoxes in Innovation Strategies and Practices. Journal of the Knowledge Economy, 5(2), 276-293.

Gordon, S., Tarafdar, M., Cook, R., Maksimoski, R. and Rogowitz, B. (2008) Improving the Front End of Innovation with Information Technology. ResearchTechnology Management, 51(3), 50-58.

Grönlund, J., Sjödin, D. R. and Frishammar, J. (2010) Open Innovation and the StageGate Process: A Revised Model for New Product Development. California Management Review, 52(3), 106-131.

Holzer, J. (2012) Construction of Meaning in Socio-Technical Networks: Artefacts as Mediators Between Routine and Crisis Conditions. Creativity and Innovation Management, 21(1), 49-60.

Khurana, A. and Rosenthal, S.R. (1998) Towards Holistic 'Front Ends' in New Product Development. Journal of Product Innovation Management, 15(1), 57-74. Kim, J., and Wilemon, D. (2002) Focusing the Fuzzy Front-End in New Product Development. R \& D Management, 32(4), 269-279. 
Kim, J. and Wilemon, D. (2003) Sources and Assessment of Complexity in NPD Projects. R\&D Management, 33(1), 15-30.

Koen, P., Ajamian, G., Burkart, R., Clamen, A., Davidson, J., D’Amore, R., Elkins, C., Herald, K., Incorvia, M. and Johnson, A. (2001) Providing Clarity and a Common Language to the 'Fuzzy Front End'. Research-Technology Management, 44(2), 46-55.

Kurkkio, M. (2011) Managing the Fuzzy Front-End: Insights from Process Firms. European Journal of Innovation Management, 14(2), 252-269.

Kvale, S. and Brinkmann, S. (2009) Interviews: Learning the Craft of Qualitative Research Interviewing, 2nd ed. Sage, Thousand Oaks, California.

Latour, B. (1987) Science in Action: How to Follow Scientists and Engineers Through Society, Harvard University Press, Cambridge, MA.

Latour, B. (1996) Aramis, or, the Love of Technology, Harvard University Press Cambridge, Cambridge, MA.

Latour, B.(1999) Pandora's Hope: Essays on the Reality of Science Studies, Harvard University Press, Cambridge, MA.

Latour, B. (2005) Reassembling the Social: An Introduction to Actor-NetworkTheory, Oxford University Press, USA, New York.

Markle, G. E., \& Petersen, J. C. (1981). Controversies in science and technology a protocol for comparative research. Science, Technology \& Human Values, 6(1), 25-30.

McGrath, R.G., MacMillan, I.C. and Tushman, M.L. (1992) The Role of Executive Team Actions in Shaping Dominant Designs: Towards the Strategic Shaping of Technological Progress. Strategic Management Journal, 13(S2), 137-61.

Martin, B., \& Richards, E. (1995). Scientific knowledge, controversy, and public decision-making. In S. Jasanoff, G. E. Markle, J. C. Petersen, and T. Pinch (eds.), Handbook of science and technology studies (pp. 506-526). Newbury Park, CA: Sage.

Martinsuo, M. and Poskela, J. (2011) Use of Evaluation Criteria and Innovation Performance in the Front End of Innovation. Journal of Product Innovation Management, 28(6), 896-914.

Murphy, S.A. and Kumar, V. (1997) The Front End of New Product Development: A Canadian Survey. R\&D Management, 27(1), 5-15.

Nobelius, D. and Trygg, L. (2002) Stop Chasing the Front End Process Management of the Early Phases in Product Development Projects. International Journal of Project Management, 20(5), 331-340.

Patton, M.Q. Qualitative Evaluation and Research Methods, Sage Publications, Newbury Park, California, 1990.

Poskela, J. and Martinsuo, M. (2009) Management Control and Strategic Renewal in the Front End of Innovation. Journal of Product Innovation Management, 26(6), 671-84.

Reid, S.E. and De Brentani, U. (2004) The Fuzzy Front End of New Product Development for Discontinuous Innovations: A Theoretical Model. Journal of Product Innovation Management, 21(3), 170-84.

Rip, A. (2012) The Context of Innovation Journeys. Creativity and Innovation Management, 21(2), 158-170.

Ritzer, G.F. (2005) Encyclopedia of Social Theory, 2nd Volume, Sage, Maryland.

Rosenthal, S.R. and Capper, M. (2006) Ethnographies in the Front End: Designing for Enhanced Customer Experiences, Journal of Product Innovation Management, 23(3), 215-37. 
Saff, D. and Ernst, M. D. (2003) Reducing Wasted Development Time Via

Continuous Testing. In Software Reliability Engineering, 2003. ISSRE 2003.

14th International Symposium (pp. 281-292).

Sayes, E. (2014) Actor-Network Theory and Methodology: Just What Does it Mean to Say that Nonhumans have Agency? Social Studies of Science, 44(1), 134-149.

Smith, P.G. and Reinertsen, D.G. (1991) Developing Products in Half the Time, Van Nostrand Reinhold, New York.

Thomke, S. and Fujimoto, T. (2000) The Effect of 'Front-Loading' Problem-Solving on Product Development Performance. Journal of Product Innovation Management. 17(2), 128-42.

Venturini, T. (2009). Diving in magma: How to explore controversies with actornetwork theory. Public Understanding of Science, 19(3), 258-273. doi:10.1177/0963662509102694

Verganti, R. (1997) Order Overplanning with Uncertain Lumpy Demand: A Simplified Theory. International Journal of Production Research, 35(12), 322948.

Verworn, B., Herstatt, C. and Nagahira, A. (2008) The Fuzzy Front End of Japanese New Product Development Projects: Impact on Success and Differences between Incremental and Radical Projects. R\&D Management, 38(1), 1-19.

Veryzer, R.W. (1998) Discontinuous Innovation and the New Product Development Process. Journal of Product Innovation Management, 15(4), 304-21.

Whatmore, S. J. (2009). Mapping knowledge controversies: Science, democracy and the redistribution of expertise. Progress in Human Geography, 33(5), 587-598.

Whittle, A. and Spicer, A. (2008) Is Actor Network Theory Critique? Organization Studies, 29(4), 611-29.

Woolgar, S. and Neyland, D. (2013) Mundane Governance: Ontology and Accountability, Oxford University Press, Oxford. 